\title{
Synthesis, Antiproliferative Activity and Molecular Docking Studies of 1,3,5-Triaryl Pyrazole Compound as Estrogen a Receptor Inhibitor Targeting MCF-7 Cells Line
}

\author{
Noval Herfindo', Riska Prasetiawati ${ }^{2}$, Daniel Sialagan ${ }^{1}$, Neni Frimayanti ${ }^{3}$, Adel Zamri $^{*}$ \\ 'Department of Chemistry, Faculty of Mathematics and Natural Sciences, Universitas Riau, \\ Jalan H.R. Subrantas KM. 12.5, 28293, Pekanbaru, Indonesia \\ ${ }^{2}$ Department of Pharmacy, Faculty Mathematics and Natural Sciences, Universitas Garut, \\ Jalan Jati No.42B, Garut, 44151, Indonesia \\ ${ }^{3}$ Department of Pharmacy, Sekolah Tinggi llmu Farmasi Riau, Jalan Kamboja, 28293, \\ Pekanbaru, Indonesia
}

*Corresponding author email: adel.zamri@lecturer.unri.ac.id

Received October 07, 2019; Accepted January 06, 2020; Available online March 15, 2020

\begin{abstract}
This research has been successfully synthesized three compounds of 1,3,5-triaryl pyrazole derivatives by two steps reaction. Firstly, pyrazoline $(4 \mathbf{a}-\mathrm{c})$ compound was obtained by one-pot reaction of aromatic ketones, aldehyde and hydrazine in basic condition. Then, pyrazole $(5 a-c)$ compound was obtained by oxidative aromatization of compound $\mathbf{4}$ in the presense of acetic acid. Chemical structure of predicted molecules was confirmed by FTIR, NMR and HRMS spectroscopy data analysis. Antiproliferative activity of compound $5 \mathrm{a}-\mathrm{c}$ were evaluated by in vitro assay against MCF-7 cells line and molecular docking simulation against ER $\alpha$ (PDB ID: 3ERT) using MOE 2019. Biological evaluation result showed that pyrazole compounds had weak antiproliferative activity against MCF-7 cells with $I_{50}$ were $>1000 \mu \mathrm{M}$, whereas the docking studies agrees the result.
\end{abstract}

Keywords: 1,3,5-triaryl pyrazole, antiproliferative, docking, ER $\alpha, M C F-7$

\section{INTRODUCTION}

Cancer is a major problem of health in both developed and developing countries. In 2018, 18.1 million cases of cancer were found, 9.6 million of which caused death, and are expected to continue to increase (Bray et al., 2018). Breast cancer cases are the second highest cause of death and the main cause among women in the world (Siegel, Miller, \& Jemal, 2019). Estrogen receptor $\alpha(E R \alpha)$ is known to be responsible for the differentiation and proliferation of this breast cancer cells (Abdel-Hafiz, 2017). Therefore, $E R \alpha$ has been targeted for treatment of breast cancer cells using anti-estrogen compounds to block estrogenic signals, through a mechanism of competition against endogenous estrogens to bind to the receptors (Muchtaridi, Dermawan, \& Yusuf, 2018).

Selective estrogen receptor modulators (SERMs) are diverse group of nonsteroidal compounds that function as ligands for ER. Tamoxifen is a SERM that has been widely used to treat breast cancer. However, tamoxifen has also been shown to have an agonist role on the bones and uterus, as well as having side effects including carcinogens (Martinkovich, Shah, Planey, \& Arnott, 2014). However, despite its ability as an antagonist against breast cancer cells, about $40 \%$ of breast cancers that have previously responded to
Tamoxifen, show intrinsic resistance (de novo resistance) (Badia, Oliva, Balaguer, \& Cavailles, 2007). This has urged researcher to find a new generation of SERMs that were structurally different from their predecessors to avoid side effects, increase their specificity and activity.

In recent years, anticancer drugs have been developed intensively from chemically synthesized compounds. Pyrazole compound has attract many scientist as drug candidate due their broad spectrum of activity such as antimicrobial (El Shehry et al., 2018), antiviral (Bhadoriya, Sharma, \& Jain, 2015), antitubercular (Pandit \& Dodiya, 2013), anticancer (Liu et al., 2019), analgesic, and anti-inflamatory (Taher, Sarg, Ali, \& Elnagdi, 2019). Specifically, 1,3,5triaryl pyrazole derivatives were reported their anticancer activity against MCF-7, MGC-803, HeLa and Huh-7 cell lines (Feng et al., 2018). Accordingly, our effort was to synthesis 1,3,5-triaryl pyrazole derivatives and biologically evaluated for its in vitro antiproliferative assay against MCF-7 cell line. To get an insight of the plausible binding modes, molecular docking studies were also performed against ER $\alpha$.

\section{EXPERIMENTAL SECTION}

The materials used in this study include 2'- chloroacetopheone (Sigma-Aldrich), 


\section{3'- bromoacetophenone \\ 4'- chloroacetophenone \\ 2- methoxybenzadehyde \\ 4- methoxybenzaldehyde}

phenylhydrazine (SigmaAldrich), potassium hydroxide (Merck), glacial acetic acid (Merck), TLC GF 254 (Merck) and organic solvents.

Compound was reacted using sealed-vessel reactor Anton Paar Monowave 50. Controlled using TLC under UV Lamp 254/365 nm (Cole-Parmer). Melting point was determined on a Fisher-Johns apparatus (uncorr). UV spectrum were recorded on Genesys $^{T M}$ 10S UV-Visible spectrophotometer. FTIR spectra were recorded in $\mathrm{KBr}$ powder on a Shimadzu ${ }^{\circledR}$ FT-IR Prestige-21 spectrophotometer. Mass spectral data were recorded on mass spectrometer (Water LCT premier XE positive mode) and ${ }^{1} \mathrm{H}-\mathrm{NMR}$ dan ${ }^{13} \mathrm{C}-\mathrm{NMR}$ spectral data were recorded on an Agilent ${ }^{\circledR}$ at 500 $\mathrm{MHz}$ and $125 \mathrm{MHz}$, respectively.

\section{Synthesis Procedure}

General synthesis procedure of pyrazoline compound

Mixture of aromatic acetophenone 1 (3 mmol), aromatic benzaldehyde 2 (3 $\mathrm{mmol})$, potassium hydroxide $(30 \%, 5 \mathrm{~mL})$ and phenylhydrazine 3 (6 $\mathrm{mmol}$ ) in ethanol $(10 \mathrm{~mL})$ was reacted in pressure tube with a stirbar using sealed-vessel reactor at $80{ }^{\circ} \mathrm{C}$ for 10 minutes. Reaction progress was controlled using TLC plates per 5 minutes reaction time. After the completion of reaction, the mixture was poured to crushed ice to yield solid product. The solid compound was filtered and washed and then recrystalized using methanol to yield pyrazoline derivatives $4 a-c$.

3-(2-chlorophenyl)-5-(2-methoxyphenyl)- 1-phenyl-

4,5-dihydro-7H-pyrazole (4a)

Molecular formula $\mathrm{C}_{22} \mathrm{H}_{19} \mathrm{CIN}_{2} \mathrm{O}$, yellow solid (40\% yield), m.p. $98-99^{\circ} \mathrm{C}$. UV $(\mathrm{EtOH}) \lambda_{\max }(\mathrm{nm}): 228$ and 315. FTIR $(\mathrm{KBr}) \overline{\mathrm{u}}\left(\mathrm{cm}^{-1}\right): 3073,2968,1598,1504$, 1389, 1138, 829. 'H NMR (500 MHz, $\left.\mathrm{CDCl}_{3}\right) \delta$ (ppm): 7.07 (d, J = 7.8 Hz, 2H, Ar-H), 7.85 (d, J = $7.8 \mathrm{~Hz}, 1 \mathrm{H}, \mathrm{Ar}-\mathrm{H}), 7.40(\mathrm{~d}, J=7.9 \mathrm{~Hz}, 1 \mathrm{H}, \mathrm{Ar}-\mathrm{H})$ 7.32-7.14 (m, 6H, Ar-H), $6.96(\mathrm{~d}, \mathrm{~J}=8.3 \mathrm{~Hz}, 1 \mathrm{H}, \mathrm{Ar}-$ $\mathrm{H}), 6.87(\mathrm{t}, \mathrm{J}=7.5 \mathrm{~Hz}, 1 \mathrm{H}, \mathrm{Ar}-\mathrm{H}), 6.81(\mathrm{t}, \mathrm{J}=7.5 \mathrm{~Hz}$, $1 \mathrm{H}, \mathrm{Ar}-\mathrm{H}), 5.65$ (dd, $J=12.3,6.8 \mathrm{~Hz}, 1 \mathrm{H}, \mathrm{Hx}), 3.95$ $\left(\mathrm{s}, 3 \mathrm{H}, \mathrm{OCH}_{3}\right), 4.09$ (dd, $\left.\mathrm{J}=17.5,12.3 \mathrm{~Hz}, 1 \mathrm{H}, \mathrm{Hb}\right)$, 3.22 (dd, J = 17.5, 6.8 Hz, 1H, Ha). HRMS (m/z): [M+H $]^{+}$calcd: 363.1264 ; found: 363.1191 .

3-(4-chlorophenyl) - 5 - (4-methoxyphenyl) - 1- phenyl -4,5-dihydro- $1 \mathrm{H}$-pyrazole (4b)

Molecular formula $\mathrm{C}_{22} \mathrm{H}_{19} \mathrm{ClN}_{2} \mathrm{O}$, white solid (46\% yield), m.p. $140-141^{\circ} \mathrm{C}$. UV $(\mathrm{EtOH}) \lambda_{\max }(\mathrm{nm})$ : 246 and 365. FTIR $(\mathrm{KBr}) \overline{\mathrm{U}}\left(\mathrm{cm}^{-1}\right): 3012,2957$, $1595,1494,1248,1089,826$. 'H NMR (500 MHz, $\left.\mathrm{CDCl}_{3}\right) \delta(\mathrm{ppm}): 7.65(\mathrm{~d}, J=8.5 \mathrm{~Hz}, 2 \mathrm{H}, \mathrm{Ar}-\mathrm{H})$, $7.35(\mathrm{~d}, J=8.5 \mathrm{~Hz}, 2 \mathrm{H}, \operatorname{Ar}-\mathrm{H}), 7.24(\mathrm{~d}, J=8.7 \mathrm{~Hz}$, $2 \mathrm{H}, \mathrm{Ar}-\mathrm{H}), 7.19(\mathrm{t}, \mathrm{J}=7.98 \mathrm{~Hz}, 2 \mathrm{H}, \mathrm{Ar}-\mathrm{H}), 7.08$ (d, J $=7.82 \mathrm{~Hz}, 2 \mathrm{H}, \mathrm{Ar}-\mathrm{H}), 6.87(\mathrm{~d}, \mathrm{~J}=8.7 \mathrm{~Hz}, 2 \mathrm{H}, \mathrm{Ar}-\mathrm{H})$, $6.80(\mathrm{t}, J=7.26 \mathrm{~Hz}, 1 \mathrm{H}, \mathrm{Ar}-\mathrm{H}), 5.23$ (dd, $J=12.0$, $7.0 \mathrm{~Hz}, 1 \mathrm{H}, \mathrm{Hx}$ ), 3.80 (dd, $J=17.0,12.0 \mathrm{~Hz}, 1 \mathrm{H}$,
$\mathrm{Hb}), 3.79\left(\mathrm{~s}, 3 \mathrm{H}, \mathrm{OCH}_{3}\right), 3.09$ (dd, J = 17.0, 7.0 $\mathrm{Hz}, 1 \mathrm{H}, \mathrm{Ha})$. HRMS (m/z): $[\mathrm{M}+\mathrm{H}]^{+}$calcd: 363.1264 ; found: 363.1307.

3-(3-bromophenyl)-5-(2-methoxyphenyl)- 1-phenyl-

4,5-dihydro- $1 \mathrm{H}$-pyrazole (4c)

Molecular formula $\mathrm{C}_{22} \mathrm{H}_{19} \mathrm{BrN}_{2} \mathrm{O}$, yellow solid $(41 \%$ yield), m.p. $110-111^{\circ} \mathrm{C}$. UV (EtOH) $\lambda_{\max }(\mathrm{nm}): 255$ and 370. FTIR (KBr) Ū $\left(\mathrm{cm}^{-1}\right):$ 3003, 2964, 1598, 1501, 1389, 1236, 739. 'H NMR (500 MHz, CDCl $) \delta$ (ppm): $\delta 7.89(\mathrm{~s}, 1 \mathrm{H}, \mathrm{Ar}-\mathrm{H}), 7.63(\mathrm{~d}, J=7.7 \mathrm{~Hz}, 1 \mathrm{H}$, Ar-H), $7.43(\mathrm{~d}, \mathrm{~J}=8.0 \mathrm{~Hz}, 1 \mathrm{H}, \mathrm{Ar}-\mathrm{H}), 7.27-7.18(\mathrm{~m}$, $4 \mathrm{H}, \mathrm{Ar}-\mathrm{H}), 7.11$ (dd, J=7.6, $1.7 \mathrm{~Hz}, 1 \mathrm{H}, \mathrm{Ar}-\mathrm{H}), 7.07$ $(\mathrm{d}, J=7.8 \mathrm{~Hz}, 2 \mathrm{H}, \operatorname{Ar}-\mathrm{H}), 6.96(\mathrm{~d}, J=8.3 \mathrm{~Hz}, 1 \mathrm{H}$, Ar-H), $6.85(t, J=7.5 \mathrm{~Hz}, 1 \mathrm{H}, \mathrm{Ar}-\mathrm{H}), 6.81(\mathrm{t}, \mathrm{J}=7.3$ $\mathrm{Hz}, 1 \mathrm{H}, \mathrm{Ar}-\mathrm{H}), 5.64$ (dd, $J=12.4,6.6 \mathrm{~Hz}, 1 \mathrm{H}, \mathrm{Hx}$ ), $3.96\left(\mathrm{~s}, 3 \mathrm{H}, \mathrm{OCH}_{3}\right), 3.83$ (dd, $\mathrm{J}=17.1,12.4 \mathrm{~Hz}, 1 \mathrm{H}$, $\mathrm{Hb}), 2.99$ (dd, J = 17.1, 6.6 Hz, 1H, Hx). ${ }^{13} \mathrm{C} \mathrm{NMR}$ (126 MHz, $\left.\mathrm{CDCl}_{3}\right) \delta$ (ppm): $\delta$ 155.98, 144.41, $135.17,131.07,129.96,129.49,128.94,128.55$, $128.50,126.50,124.11,122.71,120.99,119.13$, $113.23,110.57,58.68,55.48,41.82$. HRMS (m/z): $[\mathrm{M}+\mathrm{H}]^{+}$calcd: 407.0759; found: 407.0741.

\section{General synthesis procedure of pyrazole compound}

Compound $4 \mathrm{a}-\mathrm{c}$ ( $1 \mathrm{mmol})$ was dissolved in glacial acetic acid $(5 \mathrm{~mL})$, then the mixture was refluxed at 85 ${ }^{\circ} \mathrm{C}$ for 24 hours. Reaction progress was controlled using TLC plates per 6 hours reaction time. After the completion of reaction, the mixture was poured to crushed ice to yield solid product. The solid compound was filtered off dried. The crude product was purified by column chromatography using $n$-hexane: ethylacetate (9:1) isocratic system to yield compound $5 a-c$.

3-(2-chlorophenyl)-5-(2-methoxyphenyl)- 1-phenyl-1Hpyrazole (5a)

Molecular formula $\mathrm{C}_{22} \mathrm{H}_{17} \mathrm{ClN}_{2} \mathrm{O}$, yellow solid $(61 \%$ yield), m.p. $110-111^{\circ} \mathrm{C}$. UV (EtOH) $\lambda_{\max }(\mathrm{nm}): 249$ and 259. FTIR (KBr) ù $\left(\mathrm{cm}^{-1}\right): 3054,2949,1596,1497$, $1356,1264,758 .{ }^{1} \mathrm{H} N M R\left(\mathrm{CDCl}_{3}\right) \delta(\mathrm{ppm}): 8.03$ (dd, $J=7.7,1.8 \mathrm{~Hz}, 1 \mathrm{H}, \mathrm{Ar}-\mathrm{H}), 7.48(\mathrm{dd}, J=7.9,1.4 \mathrm{~Hz}$, $1 \mathrm{H}, \mathrm{Ar}-\mathrm{H}), 7.40-7.22(\mathrm{~m}, 9 \mathrm{H}, \mathrm{Ar}-\mathrm{H}), 7.07$ (s, 1H, pyrazole ring-H), $7.02(\mathrm{dt}, \mathrm{J}=7.5,1.1 \mathrm{~Hz}, 1 \mathrm{H}, \mathrm{Ar}-\mathrm{H})$, $6.83(\mathrm{~d}, \mathrm{~J}=8.3 \mathrm{~Hz}, 1 \mathrm{H}, \mathrm{Ar}-\mathrm{H}), 3.41\left(\mathrm{~s}, 3 \mathrm{H}, \mathrm{OCH}_{3}\right)$. HRMS (m/z): $[M+H]^{+}$calcd: 361.1108; found: 361.1130 .

3-(4-chlorophenyl)-5-(4-methoxyphenyl)- 1-phenyl-1Hpyrazole (5b)

Molecular formula $\mathrm{C}_{22} \mathrm{H}_{17} \mathrm{CIN}_{2} \mathrm{O}$, yellow solid $(63 \%$ yield), m.p. $107-108^{\circ} \mathrm{C}$. UV (EtOH) $\lambda_{\max }(\mathrm{nm}): 222$ and 256. FTIR $(\mathrm{KBr}) \bar{U}\left(\mathrm{~cm}^{-1}\right): 3016,2957,1595,1491$, 1246, 1093, 831. 'H NMR $\left(\mathrm{CDCl}_{3}\right) \delta$ (ppm): $7.40(\mathrm{~d}$, $J=8.6 \mathrm{~Hz}, 1 \mathrm{H}), 7.86(\mathrm{~d}, J=8.6 \mathrm{~Hz}, 1 \mathrm{H}), 7.86(\mathrm{~d}, J$ $=8.6 \mathrm{~Hz}, 1 \mathrm{H}), 7.38-7.29(\mathrm{~m}, 5 \mathrm{H}), 7.40(\mathrm{~d}, \mathrm{~J}=8.6$ $\mathrm{Hz}, 1 \mathrm{H}), 7.20(\mathrm{~d}, J=8.6 \mathrm{~Hz}, 1 \mathrm{H}), 6.86(\mathrm{~d}, J=8.8 \mathrm{~Hz}$ $1 \mathrm{H}), 6.86(\mathrm{~d}, \mathrm{~J}=8.8 \mathrm{~Hz} 1 \mathrm{H}), 6.74(\mathrm{~s}, 1 \mathrm{H}$, pyrazole ring- $\mathrm{H}), 3.83\left(\mathrm{~s}, 3 \mathrm{H},-\mathrm{OCH}_{3}\right)$. HRMS $(\mathrm{m} / \mathrm{z}):[\mathrm{M}+\mathrm{H}]^{+}$ calcd: 361.1108; found: 361.1094. 
3-(3-bromophenyl)-5-(2-methoxyphenyl)-7-phenyl-1Hpyrazole (5c)

Molecular formula $\mathrm{C}_{22} \mathrm{H}_{17} \mathrm{BrN}_{2} \mathrm{O}$, yellow solid $(42 \%$ yield); m.p. $53-54^{\circ} \mathrm{C}$. UV (EłOH) $\lambda_{\max }(\mathrm{nm}): 256$ and 273. FTIR $(\mathrm{KBr}) \overline{\mathrm{U}}\left(\mathrm{cm}^{-1}\right): 3001,2959,1597,1497$, $1396,1247,754 .{ }^{1} \mathrm{H} N M R\left(\mathrm{CDCl}_{3}\right) \delta(\mathrm{ppm}): \delta 8.12(\mathrm{t}$, $J=1.8 \mathrm{~Hz}, 1 \mathrm{H}), 7.86(\mathrm{dt}, J=7.8,1.3 \mathrm{~Hz}, 1 \mathrm{H}), 7.46$ (ddd, $J=8.0,2.1,1.1 \mathrm{~Hz}, 1 \mathrm{H}), 7.41-7.21(\mathrm{~m}, 8 \mathrm{H})$, $7.01(\mathrm{td}, J=7.5,1.1 \mathrm{~Hz}, 1 \mathrm{H}), 6.83(\mathrm{~d}, J=8.3 \mathrm{~Hz}$ $1 \mathrm{H}), 6.78(\mathrm{~s}, 1 \mathrm{H}$, pyrazole ring- $\mathrm{H}), 3.41(\mathrm{~s}, 3 \mathrm{H})$. HRMS $(\mathrm{m} / \mathrm{z}):[\mathrm{M}+\mathrm{H}]^{+}$calcd: 405.0602; found: 405.0613 .

\section{Molecular Docking}

Docking studies were carried out using Molecular Operating Environment 2019.0101 software (MOE of Chemical Computing Group Inc). Crystal structure of human estrogen $\alpha$ receptor (ER $\alpha$ ) (PDB ID: 3ERT) was taken from Protein Data Bank. Receptor protein was prepared using structure preparation wizard. All hydrogens were added and residue issues were corrected. Afterwards, the protein was energy minimized using AMBER:EHT14 forcefields. Ligand compound was sketched using MOE molecule builder, then prepared by using same method. Natural ligand location pocket was selected as docking site. Poses for synthesized compounds was scored by initial rescoring methodology (London $\mathrm{dG}$ ) and the final rescoring methodology (GBVI/WSA) by placement using Triangle Matcher protocol and post-placement refinement was Rigid Receptor. Proposed docking protocol was validated by re-docking of the cocrystallized the native ligand into the active site of
3ERT. Lowest binding energy conformations were picked and visualized using Ligand Scout 4.3.

\section{Antiproliferative Assay}

Antiproliferative assay against MCF-7 cell line was performed using MTS assay. Cells were cultured into 96-well plates with a density of 17,000 cells/well, then incubated at $37{ }^{\circ} \mathrm{C}$ and $5 \% \mathrm{CO}_{2}$ until the percentage of cell growth reaches $70 \%$. Then the cells were treated with samples with eight variants of concentration to each well of $100 \mu \mathrm{L}$ and then incubated for 24 hours at $37{ }^{\circ} \mathrm{C}$ and $5 \% \quad \mathrm{CO}_{2}$. Afterwards $100 \mathrm{ml}$ of PrestoBlue ${ }^{\text {TM }}$ reagent were added $(10 \%$ in the media) to the cells and then incubate for 1-2 hours. Furthermore absorbance was measured at a wavelength of $570 \mathrm{~nm}$ using a multimode reader. Concentration of compounds with $50 \%$ cell growth inhibition is expressed as the median value of inhibitory concentration $\left(\mathrm{IC}_{50}\right)$.

\section{RESULTS AND DISCUSSION \\ Chemistry}

1,3,5-Triaryl pyrazole derivatives were successfully synthesized by two steps reaction as per Figure 1 . Firstly, pyrazoline compounds prepared by one-pot synthesis method reported by Zamri, Teruna, Wulansari, Herfindo, \& Ikhtiarudin, (2019), whereas aromatic substituted acetophenone, aromatic substituted benzaldehyde and phenylhydrazine were reacted in basic condition using sealed-vessel reactor at $80{ }^{\circ} \mathrm{C}$ to obtain pyrazoline $4 \mathrm{a}-\mathrm{c}$, followed by oxidative aromatization of pyrazoline in the presence of acetic acid to obtain pyrazole 5 a-c compounds with good yields.
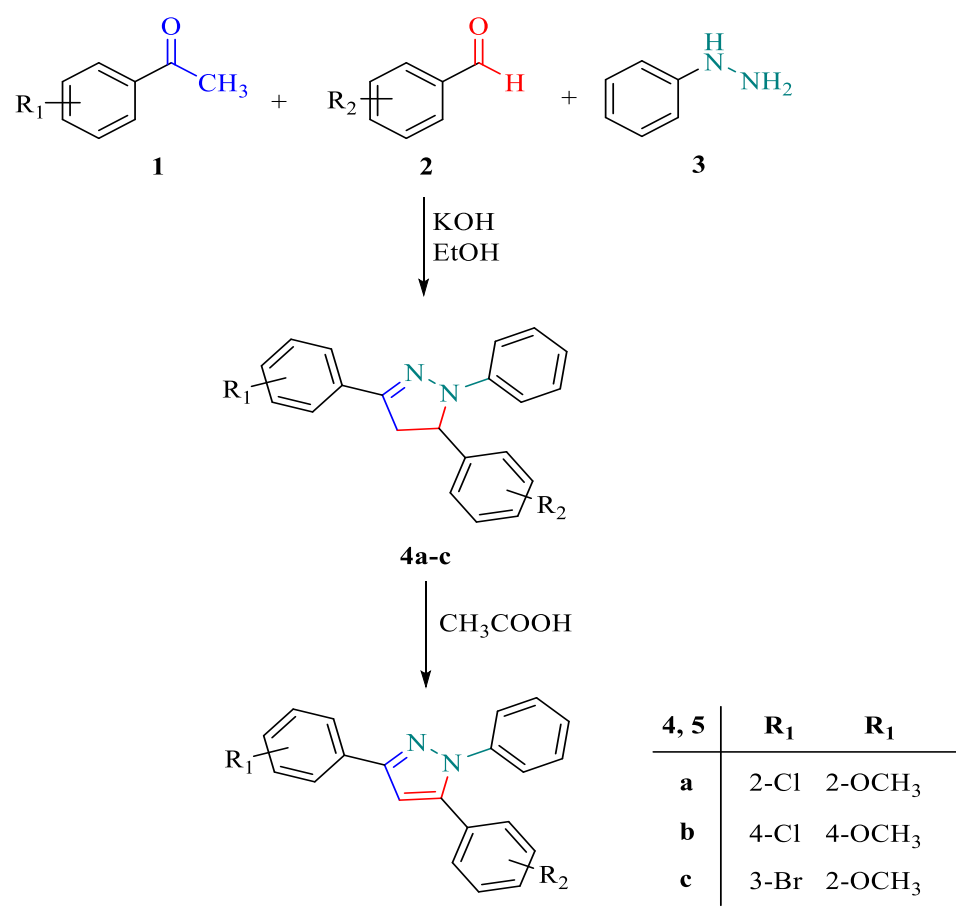

5a-c

Figure 1. Protocol of synthesis 1,3,5-triaryl pyrazole derivatives. 
<smiles>[R]C=CC(C)=CCCCCC[N+]N[R3]</smiles><smiles>[R]C1=NN([R3])C([R2])C1</smiles>

Figure 2. Proposed reaction mechanism of one-pot synthesis of pyrazoline.<smiles>[R]C1=NN([R3])C([R2])C1</smiles>

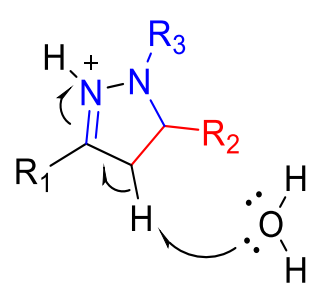<smiles>CC=C[O-]</smiles><smiles>[R]c1cc([R])n([R3])n1</smiles>
$\mathrm{H}$<smiles></smiles>

Figure 3. Proposed reaction mechanism of oxidative aromatization of pyrazoline to pyrazole.

The proposed reaction mechanism of one-pot pyrazoline synthesis is initiated by the attack of the hydroxide ion of strong base catalyst which acts as a nucleophile to the acidic $\mathrm{H} \alpha$ of the ketone compound to form the enolate ion. Enolate ions that are formed will attack the aldehydes which act as electrophiles to form $\beta$-hydroxy chalcone as intermediate compounds, followed by dehydration to form chalcone. Afterwards, the cyclization reaction occurs between chalcone with phenylhydrazine to form pyrazoline compounds (Figure 2). Meanwhile, oxidative aromatization of pyrazoline to form pyrazole compound was initiated by protonation of tertiery nitrogen atom (N2) of pyrazoline ring by taking $\mathrm{H}^{+}$ions derived from acetic acid compounds. This is due to the nitrogen atom in the pyramid ring being alkaline so that they can react with $\mathrm{H}^{+}$. Then the $\mathrm{C}=\mathrm{N}$ double bond in the pyrazoline ring will donate its electrons to the protonated nitrogen, followed by losing hidrogen atom at $\mathrm{C} 3$ and $\mathrm{C} 4$ to form double bond. Furthermore, N2 atom will release the hidrogen atom to form a pyrazole ring (Figure 3). 


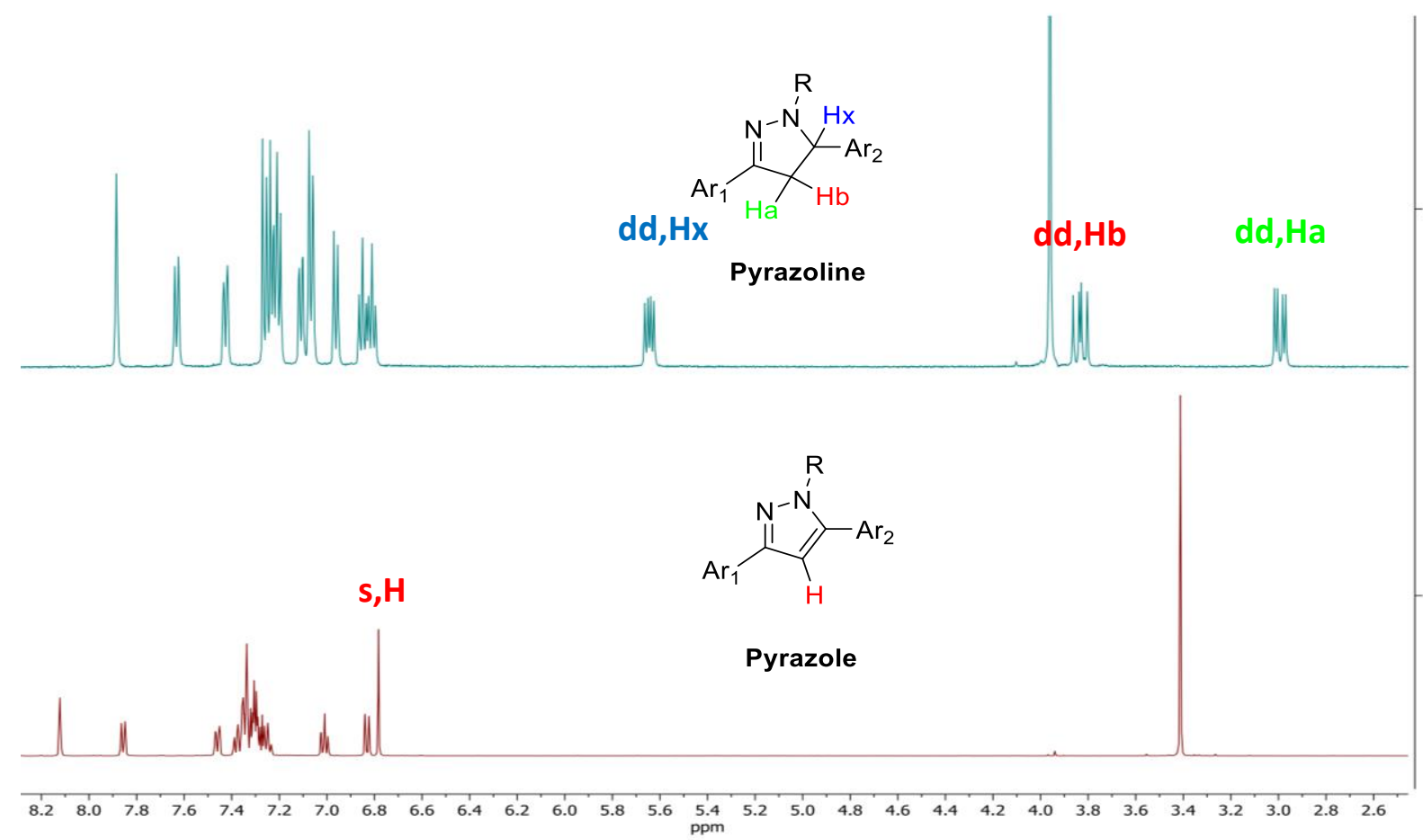

Figure 4. NMR spectra of pyrazoline $4 \mathrm{c}$ and pyrazole $5 \mathrm{c}$ comparison.

The elucidation of FTIR, NMR and HMRS spectra confirmed the structure of synthesized compounds. FTIR spectra of pyrazoline and pyrazole was relative similar because there is no significant group changes in the structure. In general, FTIR spectra showed absorption bands $\left(\mathrm{cm}^{-1}\right)$ around 1590 and 750 which indicate $\mathrm{C}=\mathrm{N}$ and $\mathrm{C}-\mathrm{X}$ bond, respectively. In ${ }^{1} \mathrm{H}-\mathrm{NMR}$ spectrum, the methoxy protons $\left(\mathrm{OCH}_{3}\right)$ appeared as singlet at $\delta$ 3.4-3.9 ppm and aromatics protons (Ar$\mathrm{H})$ appeared around $\delta 6-8 \mathrm{ppm}$. Protons of the pyrazoline ring $(\mathrm{Ha}, \mathrm{Hb}$ and $\mathrm{Hx})$ appeared as double of doublets at around $\delta 3.0,4.0$ and $5.0 \mathrm{ppm}$, respectively, due anisotropic effect of chiral carbon at C5 of pyrazoline ring. Otherwise, the oxidation of pyrazoline ring to pyrazole results significant changes whereas the proton of pyrazole ring appeared as singlet at $\delta 6.7-7.0 \mathrm{ppm}$. The comparison of both ${ }^{1} \mathrm{H}$ NMR spectra of pyrazoline $4 \mathrm{c}$ and pyrazole $5 \mathrm{c}$ was presented in Figure 4. Furthermore, HRMS spectra showed molecular ion peaks $(\mathrm{M}+\mathrm{H})^{+}$of pyrazoline and pyrazole compounds were appeared with high intensity. The difference of two in molecular weight of both compounds also confirms there are two hydrogens loss at $\mathrm{C} 4$ and $\mathrm{C} 5$ of pyrazoline ring.

\section{Antiproliferative Activity Studies}

In vitro cytotoxicity of synthesized pyrazole compound was determined by the MTS assay against MCF-7 (human breast cancer) cell line. The MTS assay is a colorimetric assay for measuring the cellular growth that reduces the blue resazurin dye to red resorufin by living cells. At a particular wavelength, the absorbance of this coloured solution can be measured and the $\mathrm{IC}_{50}$ values were calculated. Based on the $\mathrm{IC}_{50}$ values, it was observed that synthesized pyrazole compounds had very low antiproliferative activity against MCF-7 cell line compared to 4 -hydroxytamoxifen (4-OHT) as positive control with $\mathrm{IC}_{50}$ were $>1000 \mu \mathrm{M}$ and $13 \mu \mathrm{M}$, respectively (Table 1).

Molecular docking simulation of pyrazole compound was also performed to identify its potential binding modes and investigate its similarity to the standard ligand binding modes. Pyrazole compounds were docked to human estrogen $\alpha$ receptor (ER $\alpha)$ (PDB ID: 3ERT), whereas 4-hydroxytamoxifen (4OHT) compound, native ligan of 3ERT, was also re-docked as comparison and also to validate the proposed docking method. Overlay of native ligand and docked pose of $4 \mathrm{OHT}$ compound to the active site showed similar binding pose of co-crystalized ERa receptor with root means square deviation (RMSD) was 0.5278 (Figure 5). Thus, the proposed docking protocol can be used for further step.

Docking results of 1,3,5-triaryl pyrazole compounds showed that all the compounds has lower docking score compared to 4OHT (Table 1), which is consistent with in vitro antiproliferative assay result against MCF-7 cell line. Based on the docking score, pyrazole compound containing bromo-substituent had better affinity than chlorosubstituents to the active site, suggesting bigger substituent at $R_{1}$ increase the activity of 1,3,5-triaryl pyrazole. However, the affinity of $5 c$ compound still far less than the affinity of $4 \mathrm{OHT}$ that we tried to identify. 
Table 1. Biological activity evaluation results of 1,3,5-triaryl pyrazole

\begin{tabular}{|c|c|c|c|c|}
\hline \multirow{2}{*}{ Compound } & \multirow{2}{*}{$I_{50}(U M)$} & \multirow{2}{*}{$\begin{array}{l}\text { Docking } \\
\text { score }\end{array}$} & \multicolumn{2}{|r|}{ Interactive residue } \\
\hline & & & Hydrophilic & Hydrophobic \\
\hline $5 a$ & $\begin{array}{c}>1000 \\
\mu \mathrm{M}\end{array}$ & -6.73 & - & $\begin{array}{l}\text { Met343, Leu346, Thr347, Leu349, Ala350 } \\
\text { Trp383, Leu384, Leu387, Met388, Leu391 } \\
\text { lle424, Leu428, Leu525 }\end{array}$ \\
\hline $5 b$ & $\begin{array}{c}>1000 \\
\mu M\end{array}$ & -6.79 & - & $\begin{array}{l}\text { Met343, Thr347, Leu346, Leu349, Ala350, } \\
\text { Trp383, Leu387, Met388, Leu391, Met421 } \\
\text { lle424, Leu525 }\end{array}$ \\
\hline $5 c$ & $\begin{array}{c}>1000 \\
\mu M\end{array}$ & -6.89 & - & $\begin{array}{l}\text { Met343, Thr347, Ala350, Leu354, Trp383, } \\
\text { Leu384, Leu387, Met388, Leu391, Ile424 } \\
\text { Leu525, Leu536 }\end{array}$ \\
\hline 4-OHT & $13 \mu \mathrm{M}$ & -9.91 & $\begin{array}{l}\text { Thr347, Asp351, } \\
\text { Glu353, Arg394 }\end{array}$ & $\begin{array}{l}\text { Met343, Leu346, Ala350, Trp383, Leu384 } \\
\text { Leu387, Met388, Leu391, Phe404, Met421 } \\
\text { lle424, Leu428, Leu525 }\end{array}$ \\
\hline
\end{tabular}

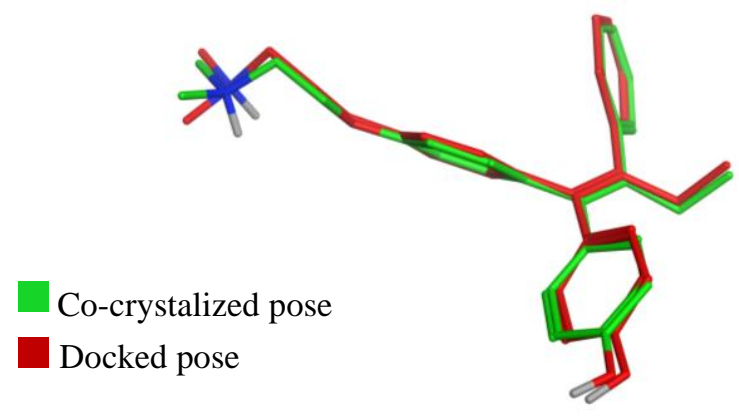

Figure 5. Binding pose of re-docked $4 \mathrm{OHT}$.
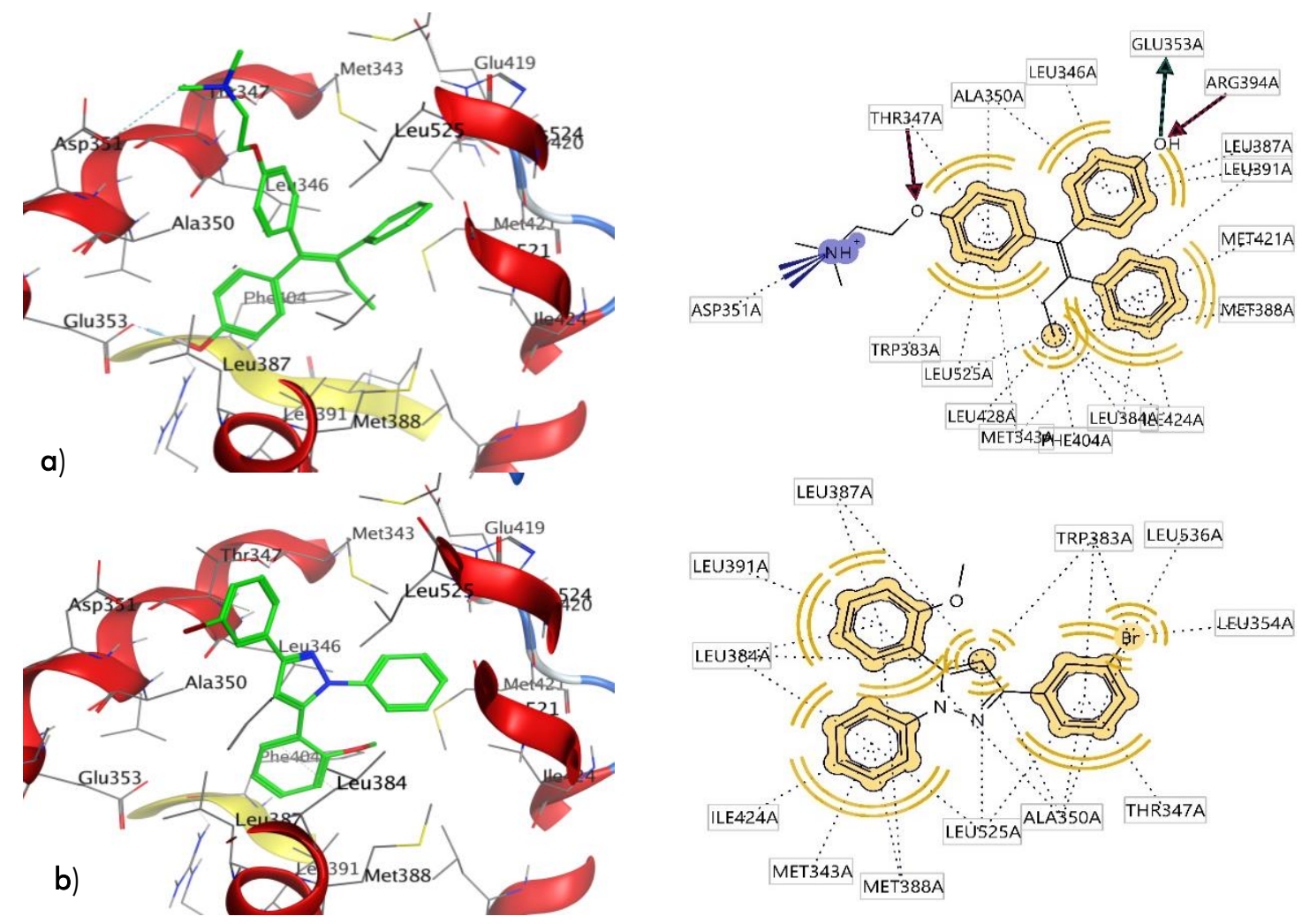

Figure 6. 3D and 2D binding mode of a) $4 \mathrm{OHT}$ and b) $5 \mathrm{c}$ compound with human ERa. 
Figure 6 illustrate the results and the binding modes of the docked $5 \mathrm{c}$ compound and $4 \mathrm{OHT}$ with amino acids residue of the active site. The $4 \mathrm{OHT}$ binding mode showed there are some hydrophobic interactions and four strong hydrophilic interactions of $4 \mathrm{OHT}$ compound to the receptor, as it interact through ionic contact via cationic amine interaction with Asp351, hydrogen bonding as hydrogen acceptor via alkoxy group with Thr347, and hydrogen bonding as hydrogen donor and acceptor via hydroxy group with Glu353 and Arg394, respectively (Figure 6a). In contrast, binding mode of $5 c$ compound into ERa active site showed there are only some hydrophobic interaction occurred, while no hydrophilic interactions because of lack of hydrogen acceptor and donor. Comparison of both binding modes of $4 \mathrm{OHT}$ and $5 \mathrm{c}$ compound revealed that hydrophilic interactions to Thr347, Asp351, Glu353 and Arg394 playing important role in antagonist activity of $4 \mathrm{OHT}$ to $E R \alpha$.

\section{CONCLUSIONS}

In this study, three 1,3,5-triaryl pyrazole been successfully synthesized by oxidative aromatization of pyrazoline in presence of acetic acid. Chemical structures of all the synthesized compounds were confirmed by FTIR, NMR, and HRMS analysis. MTS assay of pyrazole compounds showed low antiproliferative activity with $I_{50}$ values were higher than $1000 \mu \mathrm{M}$. Molecular docking of 5a-c compound to estrogen $\alpha$ receptor agrees the result as the docking score of the compounds were higher compared with 4 -hydroxytamoxifen as positive control. Molecular docking also revealed that targeted compound lacks of hydrophilic interaction to Thr347, Asp351, Glu353, and Arg394 amino acid residue. Thus, the synthesized 1,3,5-triaryl pyrazole compounds still need further development to increase their activity also its safety and side effect compared to tamoxifen.

\section{ACKNOWLEDGEMENTS}

The authors thank to Ministry of Research, Technology and Higher Education of Indonesia, for fully funded by this research through PDUPT grant with contract number of 751/UN.19.5.1.3/PT.01.03/2019 and we thank to PT. Equiva Ligand Indonesia for supplying the consumable for sealed-vessel reactor Anton-Paar, Monowave 50.

\section{REFERENCES}

Abdel-Hafiz, H. (2017). Epigenetic mechanisms of tamoxifen resistance in luminal breast cancer. Diseases, 5(3), 16. https://doi.org/10.3390/diseases5030016

Badia, E., Oliva, J., Balaguer, P., \& Cavailles, V. (2007). Tamoxifen resistance and epigenetic modifications in breast cancer cell lines. Current Medicinal Chemistry, 14(28), 3035-3043. https://doi.org/10.2174/0929867077827940 23
Bhadoriya, K. S., Sharma, M. C., \& Jain, S. V. (2015). 2,4-Dihydropyrano[2,3-c]pyrazole: Discovery of new lead as through pharmacophore modelling, atom-based 3D-QSAR, virtual screening and docking strategies for improved anti-HIV-1 chemotherapy. Journal of Taibah University for Science, 9(4), 521-530. https://doi.org/ 10.1016/i.jłusci.2014.12.005

Bray, F., Ferlay, J., Soerjomataram, I., Siegel, R. L., Torre, L. A., \& Jemal, A. (2018). Global cancer statistics 2018: GLOBOCAN estimates of incidence and mortality worldwide for 36 cancers in 185 countries. CA: A Cancer Journal for Clinicians, 68(6), 394-424. https://doi.org/10.3322/caac.21492

El Shehry, M. F., Ghorab, M. M., Abbas, S. Y., Fayed, E. A., Shedid, S. A., \& Ammar, Y. A. (2018). Quinoline derivatives bearing pyrazole moiety: Synthesis and biological evaluation as possible antibacterial and antifungal agents. European Journal of Medicinal Chemistry, 143, 14631473.

https://doi.org/10.1016/i.ejmech.2017.10.046

Feng, J., Qi, H., Sun, X., Feng, S., Liu, Z., \& Song, Y. (2018). Synthesis of novel pyrazole derivatives as promising DNA-binding agents and evaluation of antitumor and antitopoisomerases I / II activities. Chem. Pharm. Bull., 66(11), 10651071.

Liv, D. C., Gao, M. J., Huo, Q., Ma, T., Wang, Y., \& Wu, C. Z. (2019). Design, synthesis, and apoptosis-promoting effect evaluation of novel pyrazole with benzo[d]thiazole derivatives containing aminoguanidine units. Journal of Enzyme Inhibition and Medicinal Chemistry, 34(01), 829-837. https://doi.org/10.1080/14756366.2019.159 1391

Martinkovich, S., Shah, D., Planey, S. L., \& Arnott, J. A. (2014). SERMS tissue specificity. Dovepress, 9, 1437-1452.

https://dx.doi.org/10.2147/CIA.S66690

Muchtaridi, M., Dermawan, D., \& Yusuf, M. (2018). Molecular docking, 3D structure-based pharmacophore modeling, and ADME prediction of alpha mangostin and its derivatives against estrogen receptor alpha. Journal of Young Pharmacists, 10(3), 252-259. https://doi.org/10.5530/iyp.2018.10.58

Pandit, U., \& Dodiya, A. (2013). Synthesis and antitubercular activity of novel pyrazolequinazolinone hybrid analogs. Medicinal Chemistry Research, 22(7), 3364-3371. https://doi.org/10.1007/s00044-012-0351-0

Siegel, R. L., Miller, K. D., \& Jemal, A. (2019). Cancer statistics, 2019. CA: A Cancer Journal for Clinicians, 69(1), 7-34. https://doi.org/10.3322/caac.21551 
Taher, A. T., Sarg, M. T. ., Ali, N. R. ., \& Elnagdi, N. $H$. (2019). Design, synthesis, modeling studies and biological screening of novel pyrazole derivatives as potential analgesic and antiinflammatory agents. Bioorganic Chemistry, 89, 103023. https://doi.org/10.1016/i.bioorg.2019.103023

Zamri, A., Teruna, H. Y., Wulansari, S., Herfindo, N., \& Ikhtiarudin, I. (2019). 3-(3,4Dimethoxyphenyl)-5-(2-fluorophenyl)-1-phenyl4,5-dihydro-1H-pyrazole. Molbank, 2019(1), 18. https://doi.org/10.3390/M1088 